\title{
Assessment of iron deposition in the heart in sickle cell patients using 3.0 Tesla cardiovascular magnetic resonance
}

\author{
El-Sayed Ibrahim ${ }^{*}$, Fauzia Rana ${ }^{2}$, Kevin Johnson ${ }^{1}$, Richard White ${ }^{1}$ \\ From 15th Annual SCMR Scientific Sessions \\ Orlando, FL, USA. 2-5 February 2012
}

\section{Summary}

This study investigates the role of 3.0T R2* imaging for measuring cardiac iron overload. Experiments were conducted on calibrated phantoms and sickle cell disease (SCD) patients. R2* imaging at 3.0T enabled assessment of wide range of iron concentrations. $\mathrm{R} 2^{*}$ values at $3.0 \mathrm{~T}$ were about double of those at 1.5T. Myocardial R2* showed weak and strong correlations with hepatic R2* and serum ferritin, respectively. In conclusion, R2* imaging at $3.0 \mathrm{~T}$ is promising technique for assessing cardiac iron overload in SCD with high sensitivity and reproducibility.

\section{Background}

Heart failure due to cardiac iron overload is the leading cause of death in sickle cell disease (SCD) patients who receive frequent blood transfusion. CMR R2* imaging at $1.5 \mathrm{~T}$ has been established for assessing iron overload. However, recent rapid growth in use of 3.0T scanners raises the question whether quantitative iron assessment will be possible at $3.0 \mathrm{~T}$, and what advantages are expected, which is investigated in this study.

\section{Methods}

Ten gel-based phantoms were prepared with different iron concentrations $(0-225 \mu \mathrm{mol} / \mathrm{g})$. The phantoms were imaged with optimized T2*-weighted sequence on Siemens $1.5 \mathrm{~T}$ and 3.0T scanners (Fig.1). T2* was measured using monoexponential curve fitting $(\mathrm{R} 2 *=1000 / \mathrm{T} 2 *)$. The optimized 3.0T sequence was tested on $9 \mathrm{SCD}$ patients. Imaging parameters: $\mathrm{TR}=200 \mathrm{~ms}$, matrix $=256 \times 192$, FOV $=380 \times 285 \mathrm{~mm}^{2}, 10$ echoes

'Department of Radiology, University of Florida, Jacksonville, FL, USA Full list of author information is available at the end of the article
$(\mathrm{TE}=1.9-21.8 \mathrm{~ms})$, scan time $=15 \mathrm{~s}$. Mid-ventricular shortaxis heart slices at late diastole, and mid-liver transaxial slices were acquired (Fig.2). Average signal intensities were measured inside regions of the heart (septal wall) and liver. Regression analysis was conducted to study relationships between $\mathrm{R}^{*}$ at $1.5 \mathrm{~T}, \mathrm{R} 2^{*}$ at $3.0 \mathrm{~T}$, and iron concentration in the phantoms; and between myocardial $\mathrm{R} 2 *$, liver R2*, and serum ferritin in patients. Bland-Altman analysis was conducted to measure inter- and intra-observer variabilities.

\section{Results}

R2* values at 3.0T were about double of those at $1.5 \mathrm{~T}$. At $1.5 \mathrm{~T} / 3.0 \mathrm{~T}, \mathrm{R} 2 *(\mathrm{~T} 2 *)$ ranged from $50.7 / 112.41 / \mathrm{s}$ $(19.7 / 8.9 \mathrm{~ms})$ to $158.7 / 344.81 / \mathrm{s}(6.3 / 2.9 \mathrm{~ms})$ at iron concentrations of 50 and $225 \mu \mathrm{mol} / \mathrm{g}$, respectively. T2* and R2* showed decreasing nonlinear and increasing linear $(r=0.98 / 0.99)$ relationships, respectively, with iron concentration (Fig.1). At 1.5T, R2* of the lowest-concentration phantom $(25 \mu \mathrm{mol} / \mathrm{g})$ was almost zero. However, $\mathrm{R} 2 *(\mathrm{~T} 2 *)$ of this phantom was $34.81 / \mathrm{s}(28.7 \mathrm{~ms})$ at $3.0 \mathrm{~T}$, which was in agreement with the established linear relationship. In patients, myocardial/hepatic $\mathrm{R} 2 *(\mathrm{~T} 2 *)$ ranged from $32.6 / 78.71 / \mathrm{s}(30.7 / 12.7 \mathrm{~ms})$ to $78.1 / 243.91 / \mathrm{s}$ $(12.8 / 4.1 \mathrm{~ms})$. The patients' serum ferritin ranged from 50 to $3162 \mathrm{ng} / \mathrm{ml}$. Myocardial R2* showed weak $(\mathrm{r}=0.78)$ and strong $(\mathrm{r}=0.91)$ correlations with hepatic $\mathrm{R} 2^{*}$ and serum ferritin, respectively. Hepatic R2* had week correlation with serum ferritin $(r=0.66)$. Bland-Altman showed no bias between repeated R2* measurements.

\section{Conclusions}

$\mathrm{R} 2 *$ imaging at 3.0T enabled assessment of wide range of iron concentrations. However, it requires perfect shimming and very short echo times. The larger liver 
R2* compared to the heart indicates early iron deposition in liver. The good correlation between myocardial $\mathrm{R}^{*}$ and serum ferritin confirms that serum ferritin provides estimate of total body iron balance and correlates with R2* in absence of liver disease, inflammation, or infection. However, serum ferritin, by itself, is not reliable indicator of cardiac iron overload. In conclusion, R2* measurement at 3.0T is promising technique for assessing cardiac iron overload in SCD with high sensitivity and reproducibility.

\section{Funding}

N/A

\section{Author details}

${ }^{1}$ Department of Radiology, University of Florida, Jacksonville, FL, USA.

${ }^{2}$ Department of Medicine, University of Florida, Jacksonville, FL, USA.

Published: 1 February 2012

doi:10.1186/1532-429X-14-S1-P194

Cite this article as: Ibrahim et al:: Assessment of iron deposition in the heart in sickle cell patients using 3.0 Tesla cardiovascular magnetic resonance. Journal of Cardiovascular Magnetic Resonance 2012 14(Suppl 1): P194.

Submit your next manuscript to BioMed Central and take full advantage of:

- Convenient online submission

- Thorough peer review

- No space constraints or color figure charges

- Immediate publication on acceptance

- Inclusion in PubMed, CAS, Scopus and Google Scholar

- Research which is freely available for redistribution

Submit your manuscript at www.biomedcentral.com/submit 